\title{
Role of the Endoscopic Ultrasonography in the Management of Gastric Lymphomas: Our Experience and Review of Literature
}

\author{
Calogero Vetro, Alessandra Romano, Giuseppe A. Palumbo, \\ Giacomo Bonanno and Francesco Di Raimondo \\ University of Catania \\ Italy
}

\section{Introduction}

The stomach is the most common extranodal site of non-Hodgkin lymphoma (NHL) accounting for 7.1 to $10 \%$ of adult NHL (Danzon et al., 2009). The most frequent histotypes of gastric lymphomas are MALT lymphomas that arise from the stomach-associated lymphatic tissue and the Diffuse Large B-Cell Lymphoma (DLBCL) (Koch et al., 2001).

Several studies have observed that in recent years both gastric-NHL incidence and survival are increasing (Danzon et al., 2009). Furthermore, the management of gastric lymphomas has changed during the last two decades with a strong reduction of surgery in flavor to conservative treatments (Yoon S.S. et al., 2004). Indeed, the progress in biologic understanding of the pathogenesis, the introduction of Helicobacter pylori (HP) eradication therapy and the introduction of conservative treatment have definitely changed the approach to the disease and gastrectomy is no longer the first choice (Fischbach, 2010). The role of $\mathrm{HP}$ is a consolidated finding and several studies have confirmed that a simple antibiotic therapy (AT) for HP eradication is an effective treatment for MALT lymphomas with limited extension (Fischback et al., 2004), whereas, for advanced gastric lymphomas, the golden standard of treatment is the antineoplastic chemotherapy with alkylating agents in monochemotherapy such as Clorambucil for MALT lymphomas and polichemotherapy together with immunotherapy such as R-CHOP for DLBCL (Zucca \& Dreyling, 2010).

The loco-regional staging of gastric lymphomas with limited disease is important in order to better understand how to treat patients and endoscopic ultrasound (EUS) technique plays in this context a pivotal role by giving information for the prevision of response to HP eradication therapy since this therapy has shown to induce a high percentage of histological remission (up to $88 \%$ ) when the disease is confined to mucosa and submucosa (Caletti et al., 2002).

However, the importance of EUS in assessing the response to treatment and the follow-up is controversial. During the last decade, some reports indicated the importance of EUS in evaluating the response to treatment and also in long-term follow-up of gastric lymphomas with limited disease (Yeh et al., 2003), whereas other recent reports indicated the importance of EUS also in the follow-up of local-advanced MALT lymphoma (Pavlović et al., 2005). That notwithstanding, the latest ESMO clinical guidelines for diagnosis, treatment and follow-up 
of gastric lymphomas does not recommend the usage of EUS in assessing the response to treatment and the follow-up in these patients (Zucca \& Dreyling, 2010).

Based on the fact that the importance of EUS in initial assessment in gastric lymphoma is incontrovertible and that its role in follow-up is not clearly established (Zucca \& Dreyling, 2010), the present work is focused in better define its role in diagnosis and follow-up.

A review of the literature will evaluate the publications on reliability of EUS in the management of patients affected by gastric lymphoma. Finally, we will present our centre experience in the management of gastric lymphomas.

\section{Primary gastrointestinal non Hodgkin's lymphomas: general concepts on epidemiology, histology and clinical presentation}

Primary gastric NHL (PGL) accounts for $30-45 \%$ of extra nodal lymphomas in western countries (Feng et al., 2009) and $80 \%$ of extra-nodal lymphomas in eastern countries, with an incidence of 0.51 and 0.29 for male and female respectively, showing an upward trend in both incidence and survival (Danzon et al., 2009).

The age of patients at diagnosis is on average 51-66 years (Danzon et al., 2009; Feng et al., 2009) with a male-female ratio of 1:1.3, even if it depends on the histotype. The most frequent histotype is MALT lymphoma, a type of indolent disease, that arise from the marginal zone of "acquired" stomach-associated lymphatic tissue and the Diffuse Large BCell Lymphoma (DLBCL), a form of aggressive malignancy (Koch et al., 2001).

The differential diagnosis between these two lymphomas is based on morphological and immune-histo-chemical evaluation.

Macroscopically, PGL lies in the sub-mucosa layer and is morfologically characterized by small cells with dense/ moderately dispersed nuclear chromatin, not noticeable nucleoli, abundant pale cytoplasm and low proliferation rate, being similar to centrocytes. In one third of PGL of MALT type plasmacytic differentiation could be noticed. This cells infiltrate around reactive follicles in an external zone called "marginal zone" converging in a larger mass. Often, lympho- epitheliod degeneration occurs with lymphoma cells disrupting the epithelium organization with eosinophilic degeneration of epithelial cells (Swerdlow et al., 2008).

Occasionally, transformed centroblast may be present in the context of PGL of MALT type, but the presence of transformed cells with round and vescicular nuclei, scanty and amphophilic cytoplasm, organized in solid or sheet-like aggregates should testify the presence of DLBCL. Additionally, in some cases, a low grade component may be present in the context of high grade lymphoma, approximately in one fifth of cases (Koch et al., 2005).

Immunophenotypic assays can help in differential diagnosis between MALT lymphoma, DLBCL and reactive inflammatory processes, being CD20, CD21, CD35 positive CD5, CD10, CD23 negative Additionally, polimerase chain reaction (PCR), detecting the product of the translocation $\mathrm{t}(14 ; 18)$ (q21;q21) may be useful in confirming the diagnosis of PGL (Swerdlow et al., 2008).

The behaviour of these histotype is quite different, being the MALT lymphoma usually localized with multiple localizations up to $25 \%$ of cases, meanwhile DLBCL often evolve infiltrating other layers of stomach with a rapidly growing mass with one or more nodal sites, with crucial implication in clinical manifestation and care.

The clinical presentation of PGL may vary according to the histological type of lymphoma. The majority of patients with PGL of MALT type present at diagnosis unspecific symptoms, related to the presence of lymphoma and the location of the malignancy. 
In a report, the German group, in the context of the GIT NHL 01/92 study (Koch et al, 2001), showed that patients present especially epigastric pain $(80.5 \%)$, loss of appetite $(46.5 \%)$, loss of weight $(23.2 \%)$, related either to " $\mathrm{B}^{\prime \prime}$ lymphoma symptoms either to the loss of appetite, fever and night sweats (11.9\%). The median duration from beginning of symptoms to diagnosis was 93 days. General symptoms include fatigue, due to blood loss and consequent anemia. In some cases, the formation of ulcers in the stomach may determine hemorrhages and haematemesis or melena, especially in DLBCL.

Mainly, symptoms are divided into two different clusters: non-alarm symptoms and alarm symptoms (Andriani et al., 2006). Non-alarm symptoms include Epigastric/abdominal pain, dyspepsia, and heartburn; meanwhile alarm symptoms comprise weight loss, vomiting, haematemesis/melena, anemia, perforation (table 1).

\begin{tabular}{ccc} 
& MALT & DLBCL \\
\hline ALARM SYMPTOMS & $\mathbf{( 2 8 \% )}$ & $\mathbf{( 5 4 \% )}$ \\
\hline NON ALARM SYMPTOMS & $\mathbf{( 7 2 \% )}$ & $\mathbf{( 4 6 \% )}$ \\
\hline
\end{tabular}

Table 1. Symptoms at presentation in PGL of MALT type and DLBCL (Andriani et al., 2010)

\section{Role of endoscopic ultrasound in diagnosis of disease}

The unspecific clinical presentation leads to an endoscopic evaluation revealing different patterns. These lesions are more frequent at antrum and gastric body (77\%) respect to the fundus ( $8 \%$ ), and only in $15 \%$ of cases they occur diffusely.

On the whole, three main patterns could be detected using gastroscopy (Kelessis et al, 2003):

1. Ulcerative $(28-85 \%)$;

2. Polipoid (5-44\%);

3. Diffuse infiltrative (5-44\%).

Usually, DLBCLs have a macroscopic presentation that may lead clinicians to suspect malignancies prior to histological confirmation, appearing as exophytic masses (fig. 1) or ulcerative lesion (fig. 2-9) or petechial hemorrhages, meanwhile low grade lymphomas appear as flat lesions, and/or enlarged gastric folds, and/or ulcers and/or erosions (Zullo et al., 2010). It is also to be considered that these lesions are not specific of lymphomas, for example petechial haemorrhages can be found in FANS-related gastritis; therefore histological evaluation is mandatory (Fig. 3).

It is also noteworthy that endoscopic ultrasound (EUS) assay is of great help in determine the differential diagnosis of large gastric folds and can spare the performance of unnecessary invasive procedures. Indeed, large gastric folds are found in several benign situations, such as Zollinger-Ellison syndrome, Menetrier's disease or lymphoid hyperplasia and malignancies, such as adenocarcinoma. Recently, the application of diathermic snare has been proposed, but is not routinely performed because the risk of major complications, including hemorrhages and perforations. EUS findings are able to predict malignancies, especially the evaluation of gastric wall thickness (especially if $\geq 4 \mathrm{~mm}$ ), the no preserved wall architecture and the enlargement of deep layers (Ginès $t$ al., 2006). This is particularly useful in the diagnosis of plastic linitis, even if more additional studies are needed (Andriulli et al., 1990). Additionally, EUS keeps also a pivotal role in defining the diagnosis of PGL. In a recent report, Fusaroli \& Caletti (Fusaroli and Caletti, 2006) observed that, in some series of gastric malignancies, traditional biopsies are positive in $50 \%$ of cases and the 


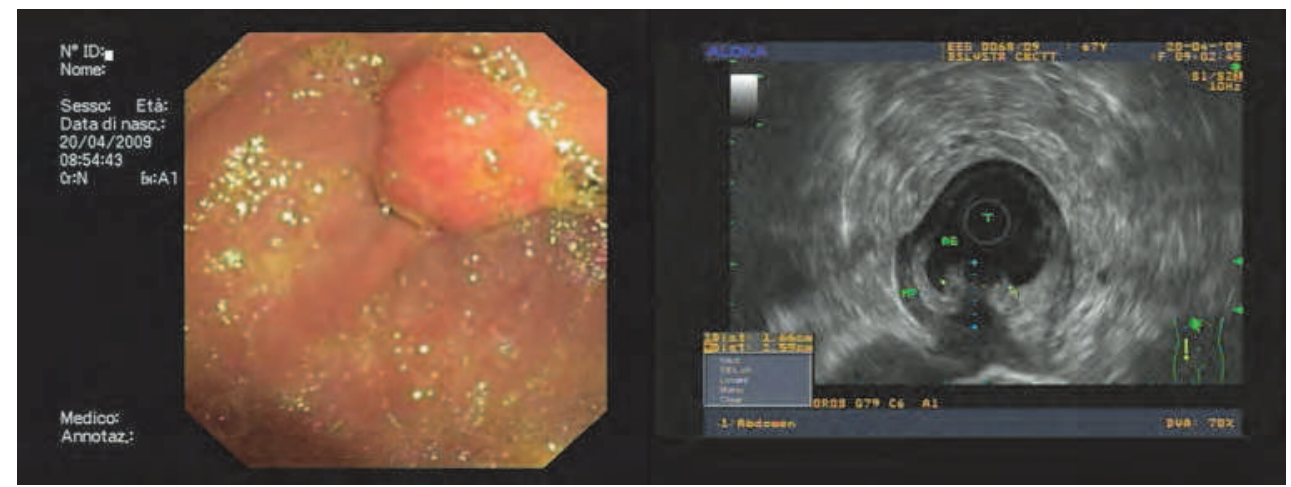

Fig. 1. Endoscopy: Polipoid lesion in the gastric antrum (left panel); histology: MALT Lymphoma; EUS (radial scanning) showing an irregularity of the gastric wall limited to the second layer (stage: T2 N0).

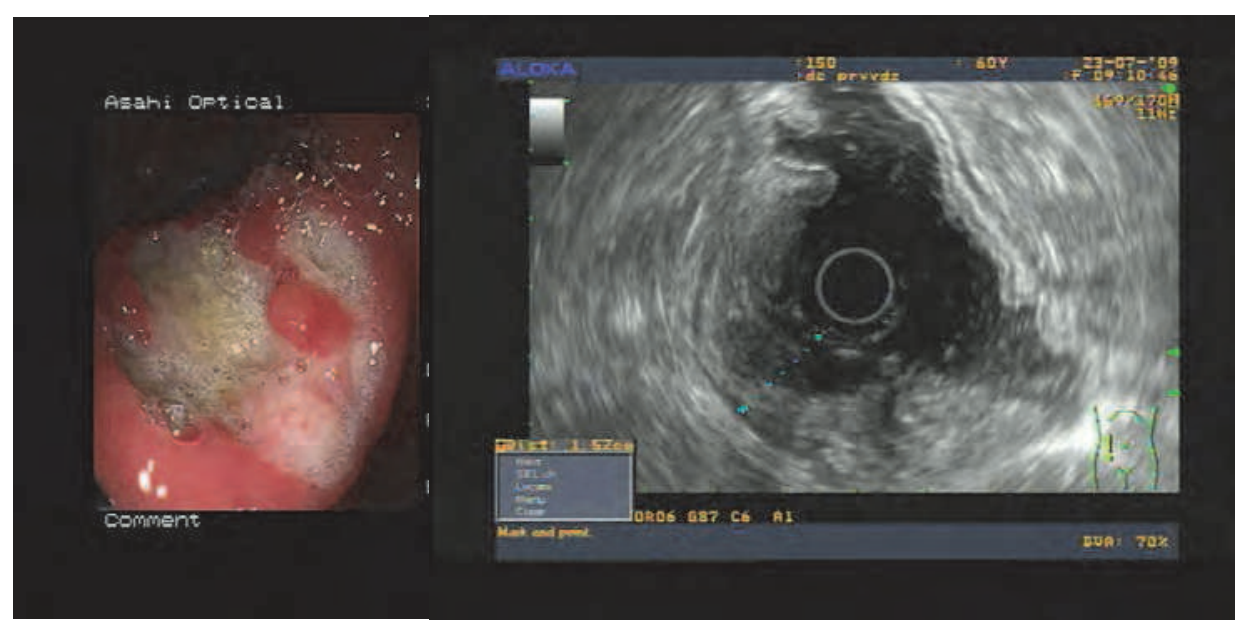

Fig. 2. Endoscopy: gastric ulcer (panel on the left); EUS (radial scanning ): irregular circumferential thickening of the gastric body with disruption of the layers and penetration of the serosa (T3 N0). Horizontal extension of the lesion bigger than endoscopic appearance

usage of large forceps has slightly increased the diagnostic sensitivity. In this prospect, EUS features have improved the diagnostic accuracy up to 89\% (Nagler, 2011), due to the peculiar echographic presentation of different malignancies, independently from the accuracy of the staging. Usually, gastric adenocarcinoma have a vertical extension with the involvement of all the layers of the gastric wall, differently from the PGL that have an horizontal growth pattern involving the gastric wall sparing the first layer. Due to this assertion, EUS is able to predict the presence of PGL more than endoscopy and biopsy alone. Furthermore, the detection of pathological nodes is a sign that induce a strong suspect of gastric malignancies. An additional advantage from using EUS in establishing diagnosis 
of PGL is related to the reduced risk of minor and major complication following biopsy, principally in presence of vascular alterations (Chen et al., 1999).

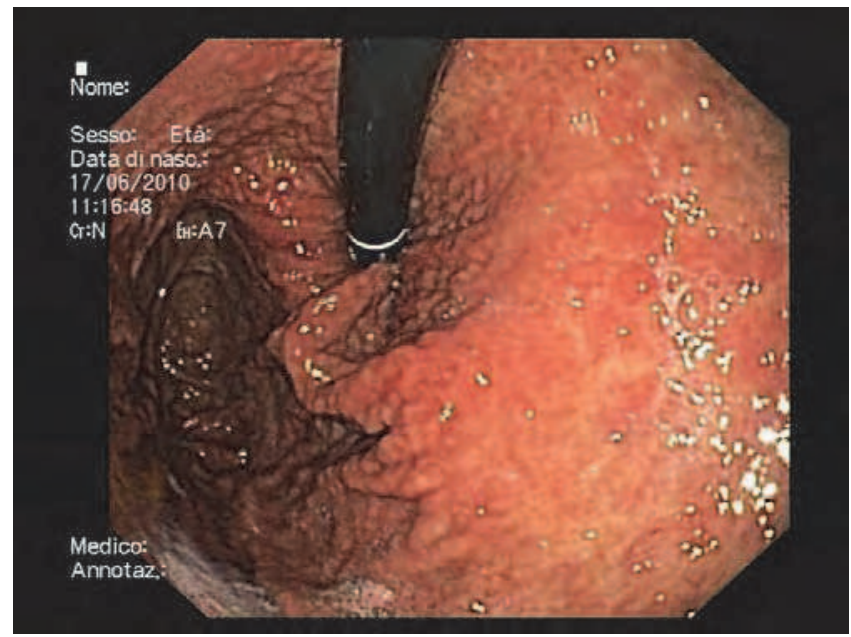

Fig. 3. Endoscopy: Micronodular gastritis. Histology revealed a low-grade MALT lynphoma

That notwithstanding, the bioptic evaluation represents the golden standard to define diagnosis of malignancies, especially in presence of sub-epithelial lesions (Karaca et al., 2010). Over the 70 publications about EUS in the management of PGL, researched using MeSH database, from 1996 to 2011, only 6 of them (8.5\%) discussed the role of EUS in determining the diagnosis of PGL. In spite of a great initial emphasis, especially when the tumor is localized to the gastric wall (Chen et al., 1999; Yücel et al., 1999; Caletti et al., 2000), subsequent studies have not confirmed these findings, giving a major importance to the ability to augment, together with bioptic evaluation, the accuracy of diagnosis (Ginès et al., 2006; Karaca et al., 2010; Nagler et al., 2011).

Biopsy is usually taken in the context of the endoscopic lesions and also randomly, in at least 8-12 regions, in order to clarify the amount of gastric wall involved by the disease and if some aggregates have transformed into more aggressive types of lymphomas. Considering that the new-formed MALT tissue in the stomach lays in the sub-mucosa, biopsies must be taken in depth; otherwise the risk is to underestimate the diagnosis. However, the introduction of large-valve biopsy forceps has improved the rate in obtaining the bioptic tissue on which establish the diagnosis (Boot \& Jong, 2002) and the application of fine needle ago-biopsy (FNAB) EUS-guided as well (Fusaroli \& Caletti, 2007) (fig. 4).

Definitive diagnosis is based on morphological and immunophenotypic evaluation. In regard to PGL of MALT type, it has been developed a score, namely Wotherspoon score, useful to differentiate it from reactive inflamation, taking into account the presence of limpho-epithelioid lesions (LEL) and the formation of follicles (table 2).

Additionally, PCR for the detection of $\mathrm{t}(14 ; 18)(\mathrm{q} 21 ; \mathrm{q} 21)$ can be also performed cause it confirms the occurrence of malignancy and, on the other hand, can assess the likelihood of response to the treatment. Furthermore, documentation of HP infection is mandatory and could be performed histologically, using Hematoxylin-Eosin and modified Giemsa staining, or with culture, urea breath test, antigen stool test or serological analysis. 


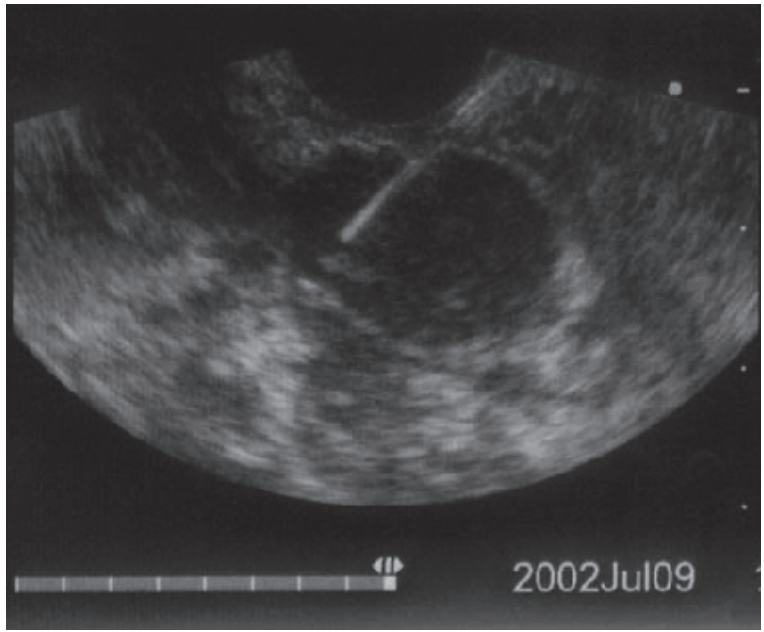

Fig. 4. EUS-guided FNAB: needle in perigastric node for cytological examination.

\begin{tabular}{|c|c|c|}
\hline SCORE & DESCRIPTION & HISTOLOGY \\
\hline 0 & Normal & $\begin{array}{l}\text { Scattered plasma cells in lamina propria. } \\
\text { No lymphoid follicles }\end{array}$ \\
\hline I & Chronic active gastritis & $\begin{array}{l}\text { Small clusters of lymphocytes in lamina } \\
\text { propria. No lymphoid follicles. No LEL }\end{array}$ \\
\hline II & $\begin{array}{l}\text { Chronic active gastritis with florid } \\
\text { lymphoid follicle formation }\end{array}$ & $\begin{array}{l}\text { Prominent lymphoid follicles with } \\
\text { surrounding mantle zone and plasma } \\
\text { cells. No LEL }\end{array}$ \\
\hline III & $\begin{array}{l}\text { Suspicious lymphoid infiltrate, } \\
\text { probably reactive }\end{array}$ & $\begin{array}{c}\text { Lymphoid follicles surrounded by small } \\
\text { lymphocytes that infiltrate diffusely in } \\
\text { lamina propria and occasionally into } \\
\text { epithelium }\end{array}$ \\
\hline IV & $\begin{array}{l}\text { Suspicious lymphoid infiltrate, } \\
\text { probably lymphoma }\end{array}$ & $\begin{array}{l}\text { Lymphoid follicles surrounded by } \\
\text { marginal zone cells that infiltrate } \\
\text { diffusely in lamina propria and into } \\
\text { epithelium in small groups }\end{array}$ \\
\hline V & MALT lymphoma & $\begin{array}{c}\text { Presence of dense infiltrate of marginal } \\
\text { zone cells in lamina propria with } \\
\text { prominent LEL }\end{array}$ \\
\hline
\end{tabular}

Table 2. Wotherspoon's score for MALT lymphoma diagnosis (Hummel et al., 2006).

\section{Endoscopic ultrasound in staging of disease}

After diagnosis, the subsequent step is the staging of disease. This, together with the HP infection, is the most important factor in establishing the treatment needed and the prognostic status.

Usually, staging is based on three main classifications (table 3): 
1. Ann Arbor classification modified by Mussshoff and Radaszkiewics (Radaszkiewicz et al., 1992);

2. Paris classification, that reproduce the TNM (Tumor-Node-Metastasis) classification for gastric cancer (Ruskoné-Fourmestraux et al., 2003);

3. Lugano classification (Rohatiner et al., 1994).

\begin{tabular}{|c|c|c|c|}
\hline Lugano & TNM & Ann Arbor & Extension \\
\hline I & T1-3 N0 M0 & IE & Mucosa, sub-mucosa, muscolaris propria \\
(fig.5-6-9)
\end{tabular}

Table 3. Staging of PGL: comparison between different systems.

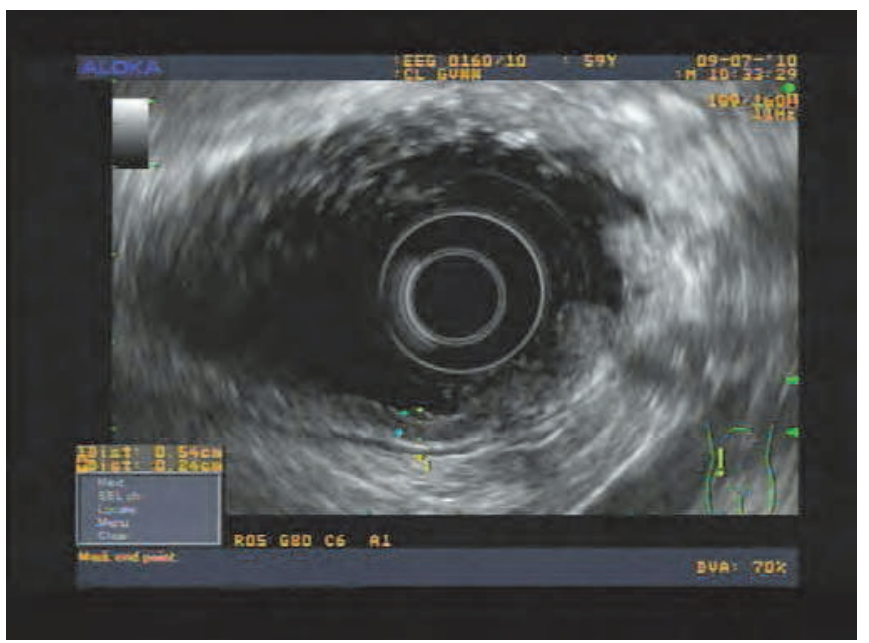

Fig. 5. EUS (radial scanning): thickening of the second layer of the gastric wall, corresponding to mucosa (stage: T1m N0)

Physical examination is useful in order to detect palpable nodes, masses in the abdomen and Waldeyer's ring involvement. Particular importance must be given to the general condition of patients, stratified with the ECOG performance status (PS), since it is a direct manifestation of the aggressiveness and stage of disease. The latest ESMO guidelines recommend additional work-up studies including complete blood counts, LDH and $\beta 2-$ microglobulin evaluation and a bone marrow aspirate and biopsy, even if a bone marrow involvement is rare.

Spiral-CT scan of neck, thorax, abdomen and pelvis with intravenous contrast is useful in order to detect masses in various body districts with a sensibility and specificity of $80 \%$ and 
$90 \%$ respectively, especially when performed with multiplanar reformations (Gligorievsky, 2009). Furthermore, 2-[fluorine-18] fluoro-2-deoxy-D-glucose (FDG)-positron emission tomography (PET) has an important role in staging and prognostic evaluation of DLBCL, but not in MALT lymphomas and is not recommended in the initial staging of PGL (Yi et al. 2010). Endoscopic Ultrasound (EUS) represents with no doubt the golden standard in determine the loco-regional staging of PGL, in particular in the era of HP eradication therapy in early stage disease.

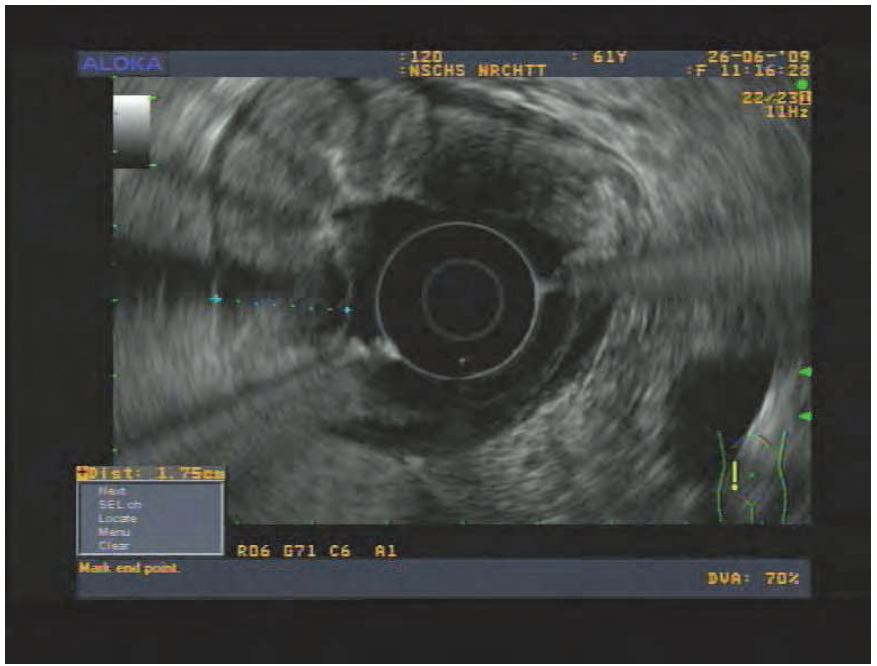

Fig. 6. EUS (radial scanning) demonstrated an irregular circumferential thickening of the gastric body with disruption of layers except for serosa (stage: T2 N0).

Due to the importance of EUS in establishing the most appropriate treatment in PGL, many papers has been published during the last decades, together with the number of publication about EUS in general (Fusaroli et al., 2010) (fig. 7).

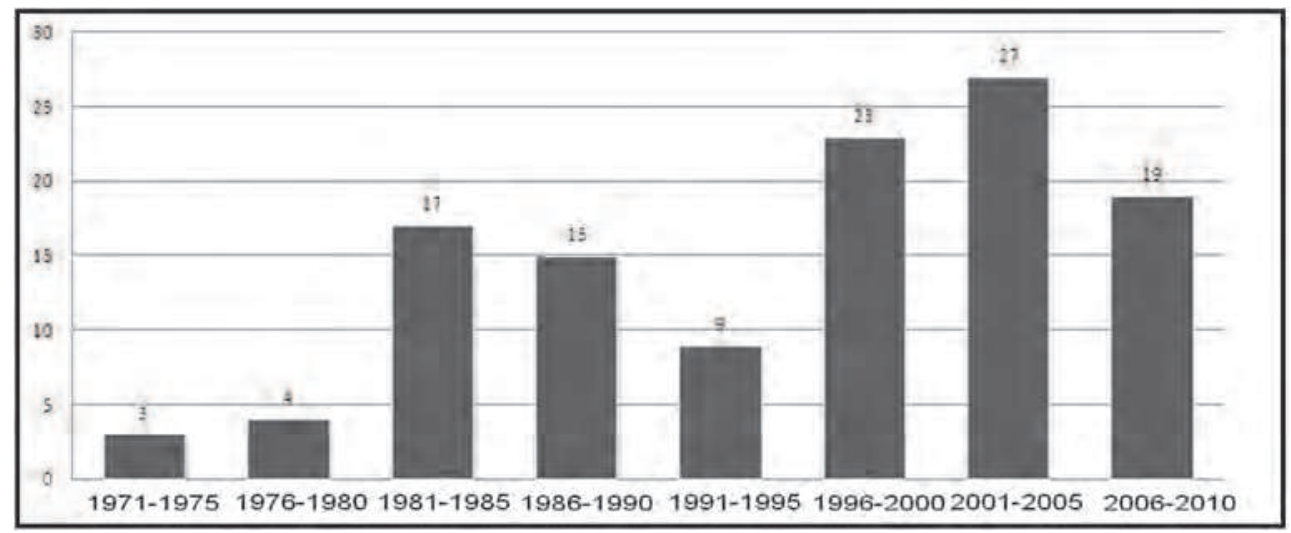

Fig. 7. Trend of published papers concerning the usage of EUS in the management of PGL. 
A bibliographic research in MeSH database, using the key words [Stomach], [Lymphoma, Non-Hodgkin] and [Ultrasonography] has revealed a total amount of 117 papers published. The majority of them have been published from the second half of '90s when has been introduced for the first time by Sackmann, in 1997, the concept that early stage PGL responds to eradication treatment (Sackmann et al., 1997).

Particularly, the last decade has viewed an escalating number of published materials, compared to previous decades with a great quantity of prospective and retrospective studies (fig. 8).

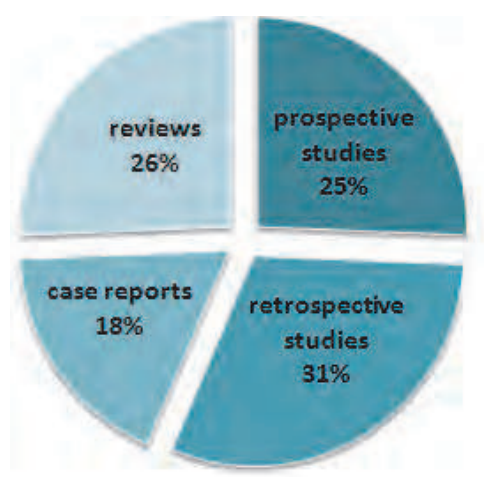

Fig. 8. Pie chart describing the typology of published papers concerning EUS in the management of PGL in the last decade.

First publications on the reliability of EUS in staging of PGL raised during the early ' 90 's (Caletti et al., 1993) reported an accuracy of $80-92 \%$ and $77-90 \%$ for $\mathrm{T}$ and $\mathrm{N}$ stage respectively. These data were not confirmed by a successive study (Fischbach et al., 2002), involving 34 centers that reported an accuracy of $59 \%$ in detecting early stages and $71 \%$ in detecting the nodes involvement. These differences are probably due to the fact that EUS is an operator-dependent technique (Janssen, 2009). In general, EUS can define pathologic lymph node, defined as size greater than $10 \mathrm{~mm}$, sharply demarcated border, echopoor structure, rounded contour (Catalano et al., 1994), better than local extension.

Due to this conflicting data, an inter-observer agreement in diagnosis and staging with EUS of gastric lesions has been investigated. Firstly, Gress et al., described how the agreement factor, called $\mathrm{k}$ factor, in diagnosing sub-epithelial masses is lower $(\mathrm{k}=0.34)$ compared to the examination of superficial lesions $(\mathrm{k}=0.53-0.8)$. Additionally, the rate of disagreement were higher between low experienced endosonographers; therefore the lowest the number of EUS performed, the higher the discordance (Gress et al., 2001). At the same time, the Italian group, in the context of the staging of PGL of MALT type, found a fair agreement for T description $(\mathrm{k}=0.38)$ and substantial agreement in $\mathrm{N}$ definition $(\mathrm{k}=0.63)$. The lowest agreement was in the definition of intermediate stage $(\mathrm{k}=0.33-0.35)$ (Fusaroli et al., 2002).

Some studies have also indicated that the usage of miniprobe (fig. 9) would have improved the accuracy in detecting lesions (Lügering et al., 2001), but additional studies are needed. Interestingly, Varas et al. defined, in a subset of 24 patients, an accuracy of EUS in defining $\mathrm{T}$ factor of $91 \%$, whereas the usage of miniprobes has given an accuracy of $88 \%$ and this mismatch was higher in evaluating the $\mathrm{N}$ factor confirming the high clinical impact of EUS (Varas et al., 2006). 
As a general rule, EUS has entered in the clinical practice of staging evaluation (Di Raimondo et al., 2007;Pavlović et al. 2005) and has been indicated as an "obligatory part of the staging procedure" (Fischbach, 2010). Thus, in the 2010 ESMO guidelines (Zucca \& Dreayler, 2010), EUS has been indicated as the most appropriate technique in defining the locoregional staging.

Conversely, EUS staging is not mandatory for DLBCL (Fischbach \& Al-Taie, 2010), being it treated as a systemic disease; even though a growing number of reports is showing its clinical utility.

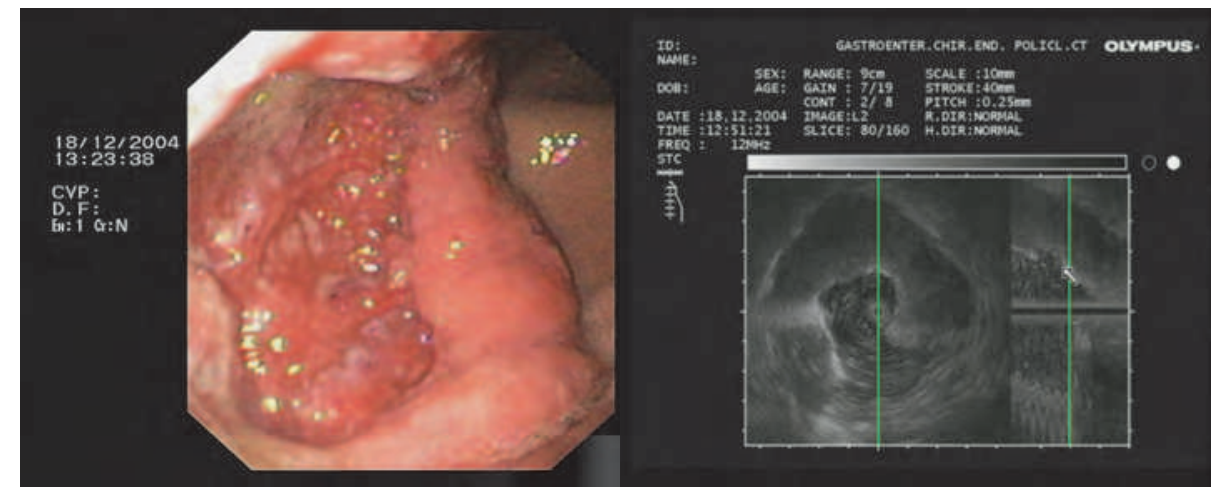

Fig. 9. Endoscopic view of ulcerated lesion of the gastric body. Histology revealed a highgrade gastric lymphoma (left panel); EUS (miniprobe): showing a circumferential irregularity of gastric wall limited at the second layer (stage: T2 N0) (right panel).

\section{Prognostic assessment and treatment: how endoscopic ultrasound staging can help in tailoring patient management}

Surely, the stage of disease assumes a great prognostic significance, being it related with survival either in pre- either post- HP eradication era; above all the bone marrow involvement represents a factor of poor outcome, together with the advanced loco-regional stage and depth of infiltration (Radaszkiewicz et al., 1992). Before the introduction of HPeradication therapy, the presence of an early stage disease represented the major indicator of response to surgery, while in HP-eradication era it designates the response to the HPtherapy itself.

Nevertheless, the most important factor in risk assessment remains the loco regional staging and EUS preserves a great importance due to the fact that it is able to indicate, with accuracy superior to other techniques, the precise loco-regional stage of disease and consequently the required treatment (Pavlović et al. 2005).

Indeed, PGL of MALT type, when confined to mucosa and sub-mucosa layers responds to HP eradication therapy without any need of chemotherapy, meanwhile DLBCL are usually treated as general disease with chemo-immuno-therapy, even if recent case reports indicated the regression of locally staged DLBCL after HP eradication (Montalban et al., 2001, Tari et al., 2009).

Independently from the stage and dissemination, transformation to DLBCL occurs in about $10 \%$ of the cases (Zucca et al., 2008). Usually, DLBCL shows a prognosis worsen than MALT 
lymphoma. However, loco-regional stage remains a central prognostic factor also in DLBCL, having patients with advanced stage (II2-III according to Lugano classification) an overall survival (OS) of $71 \%$ at 5 years, whereas patients in early stage (I-II1according to Lugano classification) have a greater OS.

\begin{tabular}{|c|c|c|c|c|c|}
\hline Reference & $\mathbf{n}$ & $\begin{array}{c}\text { Staging } \\
\text { procedure }\end{array}$ & \% CR & $\begin{array}{c}\text { Time to } \\
\text { CR } \\
\text { (months) }\end{array}$ & $\begin{array}{c}\text { No. of } \\
\text { relapses }\end{array}$ \\
\hline Wotherspoon et al., 1993; & 6 & US & 83 & --- & -- \\
\hline Savio et al., 1996; & 12 & CT & 84 & $2-4$ & 0 \\
\hline Pinotti et al., 1997; & 45 & CT & 67 & $3-18$ & 2 \\
\hline Neubauer et al., 1997; & 50 & CT+EUS & 80 & $1-9$ & 5 \\
\hline Nobre-Leitão et al., 1998; & 17 & CT+EUS & 100 & $1-12$ & 1 \\
\hline Steinbach et al., 1999; & 23 & CT+EUS & 56 & $3-45$ & 0 \\
\hline Montalban et al., 2001; & 19 & CT+EUS & 95 & $2-19$ & 0 \\
\hline Ruskoné-Fourmestraux et al., 2001; & 46 & CT+EUS & 79 & $2-18$ & 2 \\
\hline Stathis et al., 2009 & 105 & CT & 76 & $5-32$ & 16 \\
\hline
\end{tabular}

Table 4. Response to antibiotics in early-stage gastric MALT lymphoma. US: ultrasonography; CT: computed tomography; EUS: endoscopic ultrasonography; n: number of patients enrolled in the study; CR: Complete remission; No. of relapses: number of relapses

The GIT NHL 02/96 study, confirming the results of the previous study GIT NHL 01/92, revealed that surgery is no longer the better strategy in early-stage low- and high-grade gastric lymphomas (Koch et al., 2005), except when perforation, bleeding or obstruction take place, proving these findings in a cohort of 363 patients. Firstly, the great impact of the stomach-preserving treatment has been suggested by Fischbach in a prospective nonrandomized trial, reporting a survival rate from $89 \%$ to $96 \%$ at 2 years for low-grade lymphomas and from $83 \%$ to $88 \%$ for high-grade lymphomas (Fischbach et al., 2000). Subsequently, randomized trials confirmed the superiority of a stomach-conservative approach compared to surgery in early stage DLBCL (Martinelli et al., 2009) and PGL of MALT type.

Interestingly, the Taiwan Cooperative Oncology Group (TCOG) performed two prospective studies, the T1296 study in low grade PGL and DLBCL(MALT) study in high grade PGL, involving 41 and 24 patients respectively. They obtained $80 \%$ of complete remission among patients involved in the T1296 study and $64 \%$ in patients enrolled in the study DLBCL(MALT), both groups being treated with HP eradicating therapy.

The same could be said about advanced-stage PGL, where the surgical approach is no longer the first choice. On the whole, for advanced gastric lymphomas, the golden standard of treatment is the antineoplastic chemotherapy with alkylating agents in monochemotherapy such as Clorambucil for MALT lymphomas and polichemotherapy together with immunotherapy such as R-CHOP for DLBCL (Zucca \& Dreyling, 2010).

With regard to relapsed low-grade early stages PGL MALT lymphomas, independently from the HP eradication, radiotherapy represents a very good treatment option, increasing the survival rate to $85-100 \%$ at 5 years. Additionally, radiotherapy could be an option in HP negative MALT lymphomas. In high-grade lymphomas radiotherapy is usually performed in presence of partial remission of disease after chemotherapy or in presence of relapse (Aleman et al., 2010). 
Of particular interest is the fact that early stage MALT PGL respond to the HP eradication in about $90 \%$ of cases, sparing chemotherapy to these patients (Andriani et al., 2009). Several regimens have been proposed, but the best strategy should be based on the expected antibiotic resistance. The first-choice regimen is triple therapy, but other regimens are effective as well.

Certainly, after the first 6 cases published in 1993 by Wotherspoon et al in the Lancet, HP eradication has become the best studied therapeutic approach with a large number of reported studies confirming that histological regression of the lymphoma can be achieved in the majority of cases (Wotherspoon et al., 1993) (table 4).

That notwithstanding, about $10 \%$ of patients do not respond to HP eradication and for these patients radiotherapy has been proposed as a good option.

\section{Response evaluation: histology vs endoscopic ultrasound}

Response assessment to treatment lacks of standard reproducible criteria. However, histological evaluation on mapping biopsies, considering histologic Wotherspoon score (table 2), has gained a great role in determining the response evaluation being it strictly related with the clinical outcome. Patients with score $\leq 2$ achieve a complete remission, while patients with score $=3$ a partial response and patients with a score $\geq 4$ have a persistent lymphoma. Recently, the European Gastro-Intestinal Lymphoma Study (EGILS) has proposed the new recommendation on the management of PGL, including EUS in establishing the response assessment. Basically, complete remission (CR) is characterized by the absence of EUS abnormalities with negative E-Bx (Fig. 10) in two subsequent evaluations, Partial remission (PR) is defined as restoration of EUS with histological persistence of lymphoma but no clinical signs of progression, Stable disease (SD) is defined by constant presence of disease at EUS and/or histology, Progressive disease (PD) is defined by expansion of endoscopic findings, or transformation into high grade lymphoma in case of MALT lymphomas, Relapse (Rel) is defined as recurrence of lymphoma documented with histology after a reached complete remission (RuskonéFourmestraux et al. 2011).

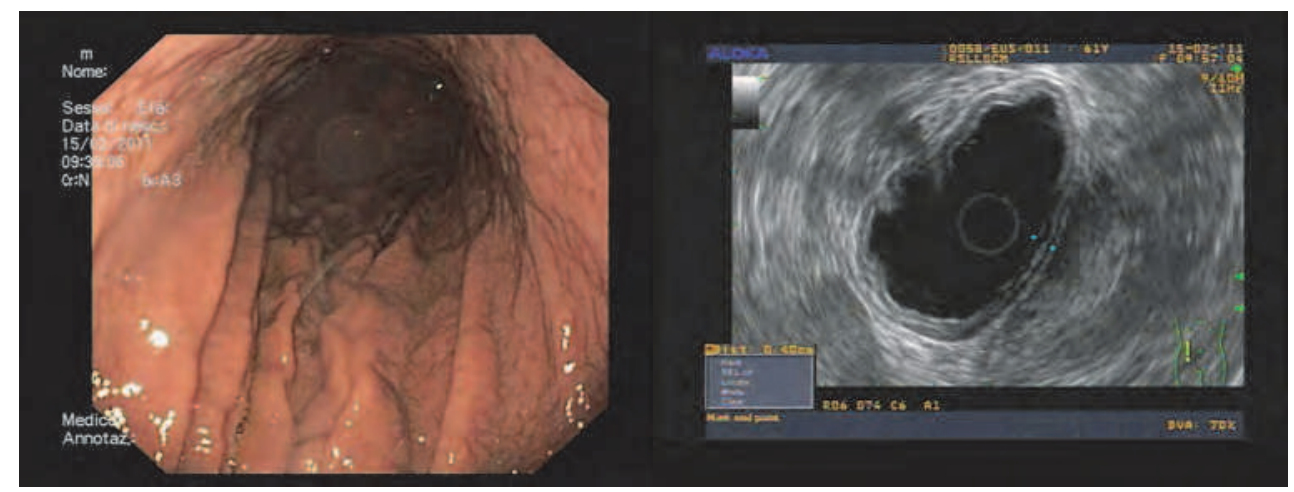

Fig. 10. Endoscopy: gastric body after eradication therapy. No histologic signs of MALT Lymphoma (left panel); EUS (radial scanning) showing a complete restoration of the gastric wall after eradication therapy (right panel). 


\section{Follow-up: is endoscopic ultrasound clinically helpful?}

Several follow-up studies have confirmed that the achievement of complete response corresponds with an augmentation of OS and PFS. The TCOG group confirmed this finding in two prospective clinical trial, the T1296 study for low-grade lymphomas and the DLBCL(MALT) study for high grade, showing an OS of $94 \%$ and $87 \%$ at 5 - and 7 - years of follow-up respectively for patients with MALT lymphoma, while DLBCL patients showed a OS of $92 \%$ and $92 \%$ at 5- and 7-years correspondingly. In these trials, patients with DLBCL that achieved complete remission have shown no relapse of disease or lymphoma-related death, meanwhile patients with MALT lymphoma, without high-grade component, showed a relapse rate of $13 \%$ in a 70 months follow-up period.

Similarly, the German group, in a multicentric prospective study involving 417 patients (Fischbach et al., 2002), demonstrated that recurrence of disease occurs in 3.9\% of MALT lymphoma and $4.7 \%$ of DLBCL. Additionally, in another multicentric trial on early stage MALT lymphoma, patients with histologically proven residual disease, have shown no recurrence of disease, except one of them that presented a transformation to DLBCL. Thus a postremission "watch and wait" strategy without further treatment can be safely adopted. Interestingly, it has been prospected that early-stage HP-negative PGL that respond to Hperadication treatment can be securely managed with the same "watch and wait" plan (Fischbach, 2010).

However, a general consensus in the management of follow-up does not exist (Zucca \& Dreyler, 2010). The ESMO group suggest to perform a strict endoscopic follow-up with multiple biopsies 2-3 months after treatment and then twice a year for two years. In certain cases, histological relapse can occur, but still a "watch and wait" approach seems to be not dangerous, even if the level of evidence is IV and the grade of recommendation is D.

Basically, there is a lack of concordance between the histological evaluation and EUS in follow-up due to the fact that even if the EUS can detect the disappearance of gastric-wall lesion, histology can identify foci of residual disease, defined as a Wotherspoon score $>2$. On the contrary, in some cases endoscopy with mapping biopsies can give negative results for residual disease, whereas EUS is positive. That can be due to the real persistence of disease that biopsies cannot detect because the depth of the infiltration or the occurrence of fibrotic tissue subsequent to the treatment (Fig. 11-12) or the presence of lesions other than lymphoma, posing the same problems when diagnosis have to be established. Residual thickness of the gastric wall could represent a scar following the chemotherapy, especially in patients affected by DLBCL (fig. 12) where it is well documented that fibrosis remains after therapy in patients with nodal presentation of disease (Canellos et al., 1988).

In the last years few studies have taken into consideration the reliability of EUS in the follow-up management of PGL (table 5).

An early report indicated that post-treatment EUS documented an abnormal thickness of the wall in three out of 11 patients affected by MALT and two of the three patients had residual lymphoma (Pavlick et al., 1997). In one case of MALT lymphoma, persistence of EUS changes was able to predict relapse of disease in absence of a "positive" biopsy. Therefore, authors concluded that the persistence of wall thickness at EUS is an indication for repeating biopsies in order to detect persistence of disease or early relapse (Levy et al, 1997). These and other small studies would indicate that EUS is a useful tool for follow-up evaluation and indicate that for patients in remission, with a restoration of normal gastric wall, a recurrent wall thickening at EUS might be indicative for relapse. However, more recent 
studies, conducted in larger series, have reduced the importance of EUS in the setting of follow-up. A study indicated that the accuracy of EUS in evaluating remission of disease was inferior to histology, with a concordance between histology and EUS present in $64 \%$ of patients. In addition, the EUS findings returned to normal in a much more prolonged time in respect to gastroscopy with biopsy. After a prolonged follow-up, however, an EUS complete remission occurred in almost every patient (Püspök et al., 2002). On the contrary, another study confirmed that EUS is reliable in determining tumor regression or relapse with a concordance between EUS and endoscopic biopsies of about $80 \%$ (Lügering et al., 2001). During 2003, two other reports stated that EUS is a reliable tool in determining the response evaluation and the early detection of disease reappearance, thus avoiding the performance of invasive procedures (Hoepffner et al., 2003; Yeh et al., 2003). In addition, the Serbian group found a stringent correlation between EUS and histology in patients treated both with HP-eradicating therapy and/or chemotherapy \pm radiotherapy (Pavlović et al. 2005).

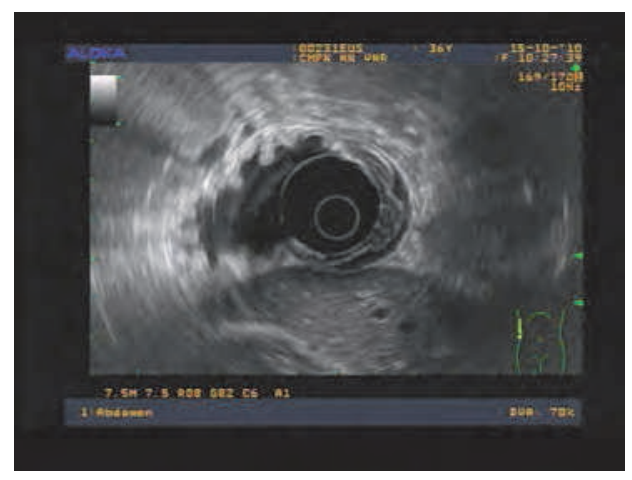

Fig. 11. Post-eradication therapy: The fourth layer persists thickened.

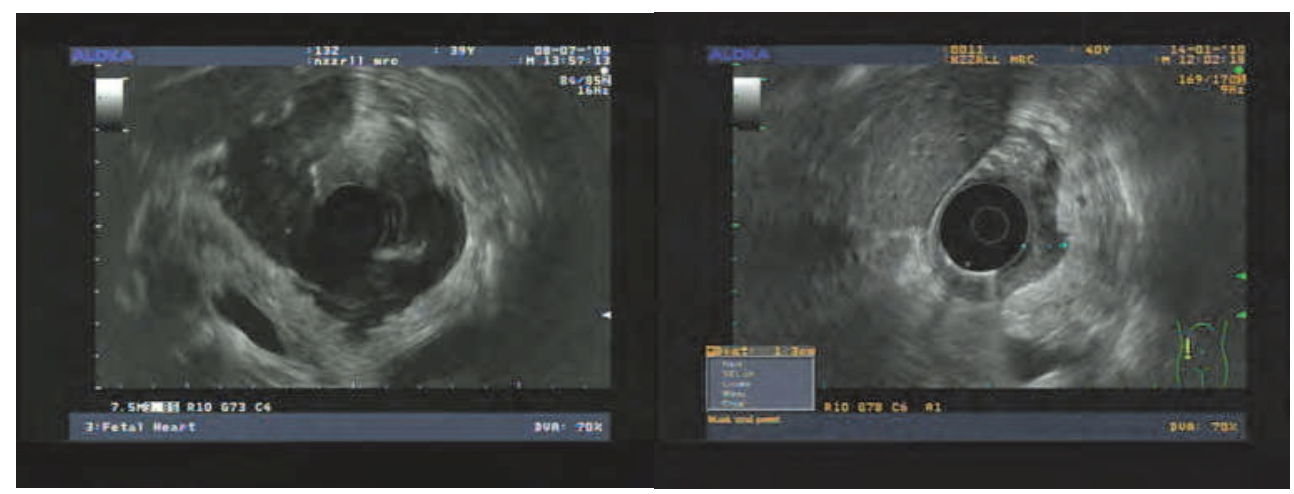

Fig. 12. EUS (radial scanning): left panel showing an high-grade gastric lymphoma infiltrating all layers of the gastric wall and the left lobe of the liver (stage: T4 N0); right panel indicates the persistence of residual abnormalities after 6 months post- chemotherapy (stage: T3 N0), even if the histology confirmed the complete response to the chemotherapy. 


\begin{tabular}{|l|llllll|}
\hline Author & Year & $\mathbf{N}$ & $\begin{array}{l}\text { Follow-up } \\
\text { (months) }\end{array}$ & $\begin{array}{l}\text { Concordance } \\
\text { EUS and } \\
\text { histology }\end{array}$ & $\begin{array}{l}\text { Time to reach } \\
\text { histological } \\
\text { response }\end{array}$ & $\begin{array}{l}\text { Time to } \\
\text { reach EUS } \\
\text { response }\end{array}$ \\
\hline Pavlick & 1997 & 11 & 2 & $90.9 \%$ & $/ / /$ & $/ / /$ \\
Lévy & 1997 & 15 & $17(4-48)$ & $50 \%$ & $/ / /$ & $/ / /$ \\
Lügering & 2001 & 24 & $22(17-28)$ & $79.16 \%$ & $/ / /$ & $/ /$ \\
Püspök & 2002 & 33 & $15(3-48)$ & $64 \%$ & 21.9 & 41.7 \\
$\begin{array}{l}\text { Yeh } \\
\text { Hoepffner }\end{array}$ & 2003 & 20 & $24(3-51)$ & $82.4 \%$ & $/ / /$ & $/ / /$ \\
$\begin{array}{l}\text { Pavlović } \\
\text { Di Raimondo }\end{array}$ & 2005 & 22 & $21(4-51)$ & $/ / /$ & $/ / /$ & $/ / /$ \\
\hline $\begin{array}{l}\text { *patients treated with } \\
\text { respectively }\end{array}$ & 2007 & 23 & $44(25-71)$ & $33 \%$ & 8 & 20 \\
\hline
\end{tabular}

Table 5. Studies concerning the reliability of EUS in the follow-up of PGL.

\section{Follow-up evaluation: experience of our group}

Our experience is not confirmatory of the aforementioned studies. In fact, in order to evaluate the role of EUS in follow-up management, our group carried out a retrospective study in gastric lymphoma patients with the aim to compare EUS with conventional endoscopy and biopsy. In our series, after a complete remission, two patients experienced a relapse and this event was not predicted by EUS nor by E-Bx. More important, we found that EUS was concordant with biopsies in only one third of patients. In addition, the EUS findings returned to normal with a considerable delayed time in respect to gastroscopy with biopsy, even after a prolonged follow-up (fig.13).

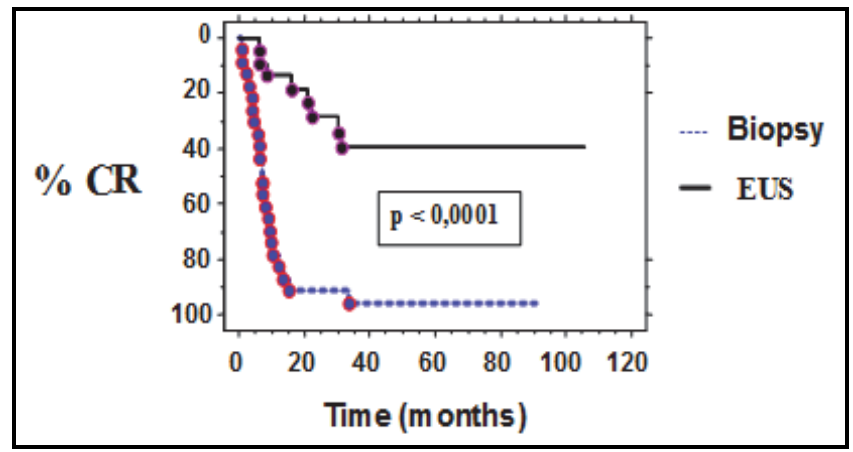

Fig. 13. Time required for achieving a complete remission by endoscopy with biopsy (E-Bx) and endoscopic ultrasound (EUS) (Di Raimondo et al. 2007)

Our series was composed by 23 patients, 11 female and 12 male, afferent at Division of Hematology, University of Catania, Italy, from January 1994 to December 2003, treated with a stomach conserving approach and with at least two EUS evaluation in the follow-up. The median age at diagnosis was 60 years ranged between 26 and 79. Sixteen patients had a low grade gastric lymphoma; while seven had a high-grade lymphoma, of whom one with a MALT lymphoma component. 
Diagnosis was based on morphological and immunophenotypic analysis, according to WHO classification, from gastric biopsies performed with endoscopy with biopsy (E-Bx). $\mathrm{HP}$ infection has been assessed by using histochemistry or urea breath test and/or the antigen stool test and has resulted as positive in the total amount of patients with low grade lymphoma (12/12) and in only 1 patient with high grade lymphoma.

At diagnosis a total of 6 patients presented alarm symptoms, 4 with low grade lymphoma and 2 with high grade lymphoma. The ulcerative pattern was the mainly represented at gastroscopy, being present in 12 patients out of 23 .

Patients have been staged at baseline with computed tomography (CT) scan of neck, thorax and abdomen, EUS and bone marrow biopsy. EUS staging was carried out according to TNM (tumour-node-metastasis) classification and the Lugano staging system (Table 6).

Response evaluation was based on the Wotherspoon score on bioptic samples. Endosonographic remission was defined as wall thickness $\leq 4 \mathrm{~mm}$ with a restoration of a normal layer pattern.

\begin{tabular}{|c|c|c|c|c|c|c|c|}
\hline & \multicolumn{6}{|c|}{ TNM } \\
\hline & & T1 N0 & T2 N0 & T3 N0 & T1-3 N1 & T1-3 N2 & T1-4 N0-3 \\
\hline \multirow{5}{*}{ 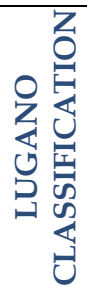 } & $\mathrm{I}$ & 3 & 6 & 1 & & & \\
\hline & II1 & & & & 6 & & \\
\hline & II2 & & & & & 3 & \\
\hline & IIIE & & & & & & 4 \\
\hline & IVE & & & & & & \\
\hline
\end{tabular}

Table 6. Extension of disease according to TNM and Lugano classification.

HP eradication with triple therapy regimen was employed in 6 patients with localized MALT lymphoma. Oral alkylating agents (either clorambucil or cyclophosphamide) or purine analogues (fludarabina, cladribine) were given, as second line treatment, in 3 out of 6 patients that failed to achieve the complete remission after AT and, as first line therapy, in 7 patients with extended MALT lymphoma. Patients with DLBCL were treated with R-CHOP (Rituximab, cyclophosphamide, doxorubicin, vincristine, and prednisone) or CHOP-like regimens with or without radiotherapy.

One patient died for hepatic failure and four more patients had a secondary neoplasia, on average 4 years after the achieved complete remission (1 colon carcinoma, 1 gastric carcinoma, 1 anaplastic NHL and 1 MALT lymphoma of small intestine).

Follow-up was conducted with endoscopic biopsies (E-Bx) in any abnormal area, or randomly if none, with EUS at variable intervals according to clinical judgment.

The echoendoscopists were unaware of the results of histology and the pathologists were unaware of the results of EUS.

At the end of initial treatment a CR was documented by biopsy in 15 (65\%) patients. At the same time only two patients showed a normalization of EUS $(\mathrm{P}=0.0002)$. Patients were then evaluated with EBs and EUS every 3/6 months and with a more prolonged follow-up (four patients) or the addition of further chemotherapy (two patients) a total of six patients in PR turned to CR so that the final number of patients in CR by E-Bx has increased to 21 (91\%). At the same time, although EUS showed a reduction of median value of thickness of gastric 
wall from 1 to $0.6 \mathrm{~cm}(\mathrm{P}=0.0031)$, only seven patients $(30 \%)$ had a normal EUS $(\mathrm{P}<0.0001)$. Complete remission, documented with E-Bx, was achieved in 18 patients with EUS restoration significantly delayed respect to E-Bx findings (26 vs 6 moths) (table 7).

\begin{tabular}{|c|c|c|c|c|c|}
\multicolumn{2}{|c}{ TIME TO REACH CR } & \multicolumn{2}{c|}{ E-Bx } & \multicolumn{2}{c|}{ EUS } \\
\cline { 2 - 6 } \multirow{3}{*}{ TOTAL } & MEDIAN & \multicolumn{2}{|c|}{6} & \multicolumn{2}{|c|}{26} \\
\cline { 2 - 6 } & RANGE & 2 & 19 & 6 & 56 \\
\hline \multirow{2}{*}{ MALT } & MEDIAN & \multicolumn{2}{|c|}{5} & \multicolumn{2}{|c|}{21} \\
\cline { 2 - 6 } & RANGE & 2 & 19 & 6 & 56 \\
\hline \multirow{2}{*}{ HIGH GRADE } & MEDIAN & \multicolumn{3}{|c|}{6} & \multirow{2}{*}{ N.A. } \\
\cline { 2 - 5 } & RANGE & 2 & 10 & \\
\hline
\end{tabular}

Table 7. Time required for achieving a complete remission by endoscopy with biopsy (E-Bx) and endoscopic ultrasound (EUS). CR: Complete Remission, N.A.: Not Available.

All the patients with MALT lymphoma, which responded to the treatment and maintained the response, eventually reached the EUS complete remission at the end of a prolonged follow-up, except for one of them that presented EUS abnormalities also after a follow-up of 114 months. On the contrary, only one patient with high grade lymphoma reached the EUS complete remission, after 30 months of follow-up.

Thus, it is possible that disappearance of lymphoma cells is a very slow process that takes several years to extinguish once the initiating factors have been eliminated. In any case, persistence of EUS abnormalities, irrespective of the fact that it indicates fibrosis or minimal residual disease, did not seem to have a clinical relevance being not predictive of relapse and should not be used as a guidance for further treatment.

A total of 120 EUS were performed, the majority of them $(97 / 120)$ within the first five years of follow-up, with a discordance rate of $61.6 \%$. Particularly, the discordance rate was $68 \%$ during the first five years of follow-up but it was reduced to $34.7 \%$, in the subsequent period; on the contrary, the concordance rate shows an upward trend at 10-years follow-up, from $32 \%$ to $65 \%$. However, taking into account the histotype, this trend seems to be confirmed for MALT lymphomas but not for DLBCL where the discordance rate, after 10 years of follow-up, remains higher than the concordance rate (Fig. 14).

On the whole, the prolonged follow-up confirmed our previous findings. In fact, EUS can detect the complete remission with a significant delay compared to E-Bx in both types of lymphoma. Additionally, EUS restoration of normal stomach layers occurs after many years from the achieved complete remission in patients with MALT lymphoma; while in patients with DLBCL EUS continues to show an abnormal pattern, despite the obtained complete remission.

\section{Conclusion}

The introduction of EUS in the management of PGL has radically changed the approach to these patients. Nowadays, EUS keeps a pivotal role in defining the sub-mucosal lesions and large gastric folds, also determining the differential diagnosis prior to the histological evaluation. The precise staging delineated by EUS assumes a critical importance in defining the prognosis and in turn tailors the therapy; nevertheless, EUS seems to be not very useful to define the response assessment, since it can show the restoration of gastric layers with a great delay compared to the histological evaluation. 


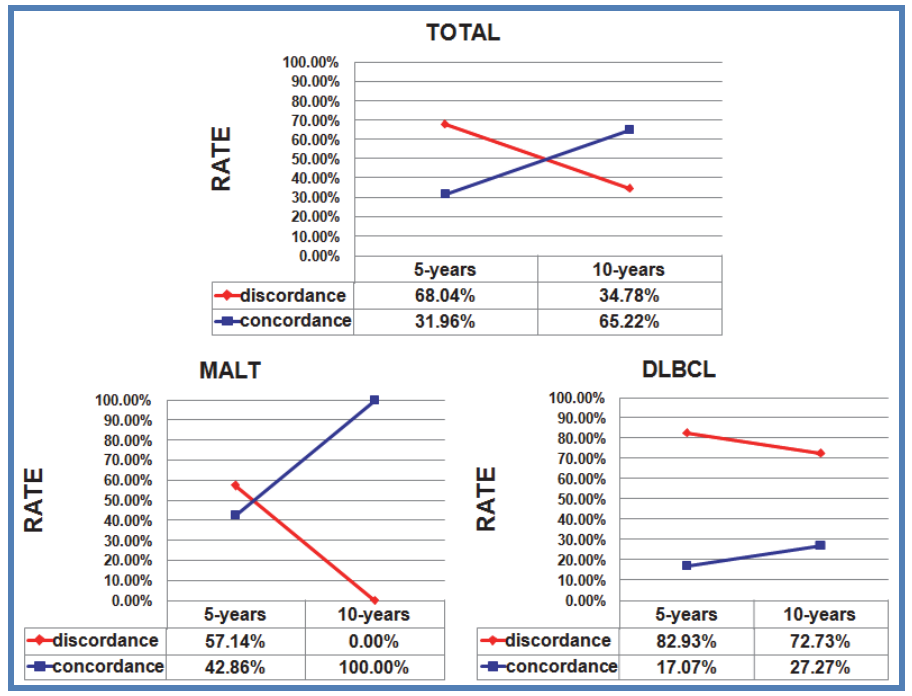

Fig. 14. Trend, at 5- and 10- years follow-up, of Discordance (red line) and Concordance (blue line) rate between E-Bx and EUS fining in the total set of patients (top panel), in patients with MALT lymphoma (left panel on the bottom) and in patients with DLBCL (right panel on the bottom).

Finally, the trustworthiness of EUS in follow-up is questionable. The latest ESMO guidelines do not recommend the performance of EUS in the follow-up. We have shown that it is not reliable in DLBCL, where most patients maintained a complete remission even with persistent EUS abnormality. In MALT patients, the role of EUS during the follow up period could be more important since we have noticed several changes in the EUS findings with a more prolonged follow up. Our study is, however, retrospective and also lies in a small number of cases. A prospective study should be carried out with an adequate number of patients so as to distinguish between DLBCL and MALT since the two diseases have different therapeutic approaches. We think that until now patients with gastric lymphoma should be treated with a conservative approach and they should be followed with both EUS and E-Bx in order to have a longer follow-up and more information on the role of EUS in detecting early relapse.

\section{References}

Aleman, B.M.; Haas, R.L. \& van der Maazen, R.W. (2010) Role of radiotherapy in the treatment of lymphomas of the gastrointestinal tract. Best Practice $\mathcal{E}$ Research Clinical Gastroenterology, Vol. 24, No. 1 (February 2010), pp.24-34, ISSN 1521-6918.

Andriani, A.; Zullo, A.; Di Raimondo, F.; Patti, C.; Tedeschi, L.; Recine, U.; Caruso, L.; Bonanno, G.; Chiarenza, A.; Lizzani, G.; Miedico, A.; Romanelli, A.; Costa, A.; Linea, C.; Marrone, C.; Mirto, S.; Mistretta, A.; Montalbano, L.; Restivo, G.; Vinci, M.; Bibas, M.; Hassan, C.; Stella, F.; Cottone, M. \& Morini S. (2006) Clinical and endoscopic presentation of primary gastric lymphoma: a multicentre study. 
Alimentary pharmacology and therapeutics.Vol. 23, No. 6, (15 March 2006), pp. 721-726, ISSN 1365-2036.

Andriani, A.; Miedico, A.; Tedeschi, L.; Patti, C.; Di Raimondo, F.; Leone, M.; Schinocca, L.; Romanelli, A.; Bonanno, G.; Linea, C.; Giustini, M.; Hassan, C.; Cottone, M. \& Zullo, A. (2009)Management and long-term follow-up of early stage H. pyloriassociated gastric MALT-lymphoma in clinical practice: an Italian, multicentre study (2009) Digestive and liver disease : official journal of the Italian Society of Gastroenterology and the Italian Association for the Study of the Liver. Vol. 41, No. 7, (July 2009), pp. 467-473, ISSN 1878-3562.

Andriulli ,A.; Recchia, S.; De Angelis, C.; Mazzucco, D.; Berti, E.; Arrigoni, A. \& Verme, G. (1990). Endoscopic ultrasonographic evaluation of patients with biopsy negative gastric linitis plastica. Gastrointestinal endoscopy, Vol. 36, No. 6, (NovemberDecember 1990), pp. 611-615, ISSN 1097-6779.

Boot, H. \& de Jong, D. (2002) Diagnosis, treatment decisions, and follow up in primary gastric lymphoma. Gut, Vol. 51, No. 5, (November 2002), pp. 621-622, ISSN 14683288

Caletti, G.; Ferrari, A.; Brocchi, E. \& Barbara, L. (1993). Accuracy of endoscopic ultrasonography in the diagnosis and staging of gastric cancer and lymphoma. Surgery, Vol. 113, No. 1, (January 1993), pp. 14-27, ISSN 1532-7361.

Caletti, G.; Fusaroli, P.; Togliani, T.; Bocus, P. \& Roda, E. (2000) Endosonography in gastric lymphoma and large gastric folds. European journal of ultrasound : official journal of the European Federation of Societies for Ultrasound in Medicine and Biology, Vol. 11, No. 1, (March 2000), pp. 31-40, ISSN 0929-8266.

Caletti, G.; Zinzani P.L.; Fusaroli P.; Buscarini E.; Parente F.; Federici T.; Peyre S.; De Angelis C.; Bonanno G.; Togliani T. ; Pileri S.; Tura S. \& The Italian Gastric Lymphoma Study Group (2002). The importance of endoscopic ultrasonography in the management of low-grade gastric mucosa-associated lymphoid tissue lymphoma. Alimentary Pharmacology and therapeutics, Vol. 16, No. 10, (October 2002), pp. 17151722, ISSN 0269-2813.

Canellos, G.P. (1988). Residual mass in lymphoma may not be residual disease. Journal of clinical oncology : official journal of the American Society of Clinical Oncology, Vol 6, No. 6, (June 1988), pp. 931-933, ISSN 1527-775.

Catalano, M.F.; Sivak, M.V.; Rice, T.; Gragg, L.A. \& Van Dam J. (1994) Endosonographic features predictive of lymph node metastasis. Gastrointestinal Endoscopy, Vol. 40, No. 4, (July-August 1994), pp. 442-446, ISSN 1097-6779.

Chen, T.K.; Wu, C.H.; Lee, C.L.; Lai, Y.C.; Yang, S.S. (1999) Endoscopic ultrasonography in the differential diagnosis of giant gastric folds. Journal of the Formosan Medical Association, Vol. 98, No. 4, (April 1999), pp. 261-264, ISSN 0929-6646.

Danzon, A.; Belot, A.; Maynadie, M.; Remontet, L.; Dupont, A.C.G.; Carbonnel, F. \& The Association FRANCIM (2009). Incidence and survival of gastric non-Hodgkin's lymphoma: A population-based study from the Association of the French Cancer Registries (FRANCIM). Acta Oncoogica, Vol. 48, No. 7, (January 2009), pp. 977-983, ISSN 0284-186X.

Di Raimondo, F.; Caruso, L.; Bonanno, g.; Naso, P.; Chiarenza, A.; Fiumara, P.; Bari A.; Palumbo, G.A.; Russo A. \& Giustolisi R. (2007). Is endoscopic ultrasound clinically useful for follow-up of gastric lymphoma. Annals of oncology : official journal of the 
European Society for Medical Oncology / ESMO, Vol. 18, No. 2, (February 2007), pp. 351-356, ISSN 0923-7534.

Feng, L.; Zhang, G.; Hu, Z.; Zou, Y.; Chen, F.; Zhang, G. \& Tang, L. (2009). Diagnosis and treatment of 81 patients with primary gastrointestinal lymphoma. Journal of Central South University. Medical sciences, Vol. 34, No. 7, (Julie 2009), pp. 582-588.

Fischbach, W.; Goebeler-Kolve, M.E. \& Greiner, A. (2002) Diagnostic accuracy of EUS in the local staging of primary gastric lymphoma: results of a prospective, multicenter study comparing EUS with histopathologic stage. Gastrointestinal Endoscopy, Vol. 56, No. 5, (November 2002), ISSN 1097-6779.

Fischbach, W.; Goebeler-Kolve, ME; Dragosics, B; Greiner, A. \& Stolte, M. (2004). Long term outcome of patients with gastric marginal zone B cell lymphoma of mucosa associated lymphoid tissue (MALT) following exclusive Helicobacter pylori eradication therapy: experience from a large prospective series. Gut, Vol. 53, No. 1, (January 2004), pp. 34-37, ISSN 1468-3288.

Fischbach, W. (2010). Long-term follow-up of gastric lymphoma after stomach conserving treatment. Best Practice E Research Clinical Gastroenterology, Vol. 24, No. 1 (February 2010), pp. 71-77, ISSN 1521-6918.

Fischbach, W. \& Al-Taie, O. (2010). Staging role of EUS. Best Practice \& Research Clinical Gastroenterology, Vol. 24, No. 1, (February 2010), pp. :13-17, ISSN 1532-1916.

Fusaroli, P.; Buscarini, E.; Peyre, S.; Federici, T.; Parente, F.; De Angelis, C.; Bonanno, G.; Meroni, E.; Napolitano, V.; Pisani, A.; Sottili, S.; Togliani, T. \& Caletti, G. (2002). Interobserver agreement in staging gastric malt lymphoma by EUS. Gastrointestinal Endoscopy, Vol. 55, No. 6, (May 2002), pp. 662-668, ISSN 10976779 .

Fusaroli, P. \& Caletti, G. (2006). EUS in the Evaluation of Gastric Wall Layer Abnormalities Non-Hodgkin Lymphoma and Other Causes, In: Endosonography, Robert H. Hawes MD, Paul Fockens MD PhD, pp. 127 - 146, Sounders Elsevier, ISBN: 1437708056 , Philadelphia.

Fusaroli, P. \& Caletti, G. (2007). Endoscopic ultrasonography, Endoscopy, Vol. 39, No. 1, (January 2007), pp.17-20, ISSN 1438-8812.

Fusaroli, P.; Kypreos, D.; Alma Petrini, C.A. \& Caletti, G. (2010). Scientific Publications in Endoscopic Ultrasonography: Changing Trends in the Third Millennium, Journal of clinical gastroenterology, Vol. 00, No. 00, (November 2010), ISSN 1539-2031.

Gligorievsky, A. (2009). CT evaluation of gastric lymphoma. Contributions / Macedonian Academy of Sciences and Arts, Section of Biological and Medical Sciences, Vol.30, No. 2, (December 2009), pp. 125-138, ISSN 0351-3254.

Gress, F.; Schmitt, C.; Savides, T.; Faigel, D.O.; Catalano, M.; Wassef, W.; Roubein, L.; Nickl, N.; Ciaccia, D.; Bhutani, M.; Hoffman, B. \& Affronti, J. (2001) Interobserver agreement for EUS in the evaluation and diagnosis of submucosal masses. Gastrointestinal Endoscopy, Vol. 53, No. 1, (January 2001), pp. 71-76, ISSN 1097-6779.

Ginès, A.; Pellise, M.; Fernández-Esparrach, G.; Soria, M.T.; Mata, A.; Membrillo, A.; Martínez-Pallí, G.; Solé, M.M.; Llach, J.; Bordas, J.M. \& Piqué, J.M. (2006). Endoscopic ultrasonography in patients with large gastric folds at endoscopy and biopsies negative for malignancy: predictors of malignant disease and clinical impact, The American journal of gastroenterology, Vol. 101, No. 1, (January 2006), pp. 64-69, ISSN 1572-0241. 
Hoepffner, N.; Lahme, T.; Gilly, J.; Koch, P.; Foerster, E.C. \& Menzel, J. (2003). Endoscopic ultrasound in the long-term follow-up of primary lymphomas of the stomach under conservative therapy. Zeitschrift für Gastroenterologie, Vol.41, No. 12, (December 2003), pp. 1151-1156, ISSN 1439-7803.

Hummel, M.; Oeschger, S.; Barth, T.F.; Loddenkemper, C.; Cogliatti, S.B.; Marx, A.; Wacker, H.H.; Feller, A.C.; Bernd, H.W.; Hansmann, M.L.; Stein, H. \& Möller, P. (2006). Wotherspoon criteria combined with B cell clonality analysis by advanced polymerase chain reaction technology discriminates covert gastric marginal zone lymphoma from chronic gastritis. Gut, Vol. 55, No. 6, (June 2006), pp. 782-787, ISSN 1468-3288.

Janssen, J. (2009). The impact of EUS in primary gastric lymphoma. Best practice $\mathcal{E}$ research. Clinical gastroenterology, Vol. 23, No. 5, (October 2009),pp. 671-678, ISSN 1532-1916.

Karaca, C,; Turner, B.G.; Cizginer, S.; Forcione, D. \& Brugge, W. (2010). Accuracy of EUS in the evaluation of small gastric subepithelial lesions. Gastrointestinal endoscopy, Vol. 71, No. 4, (April 2010), pp. 722-727, ISSN: 1097-6779.

Kelessis, N.G.; Vassilopoulos, P.P.; Tsamakidis, K.G.; Bai, M.G.; Avital, S. \& Rosenthal, R.J. (2003) Is gastroscopy still a valid diagnostic tool in detecting gastric MALT lymphomas? A dilemma beyond the eye. Mucosa-associated lymphoid tissue. Surgical endoscopy, Vol. 17, No. 3, (March 2003), pp. 469-74, ISSN 1432-2218

Koch, P.; del Valle, F.; Berdel, W.E.; Willich, N.A.; Reers, B.; Hiddemann, W.; GrothausPinke, B.; Reinartz, G.; Brockmann, J.; Temmesfeld, A.; Schmitz, R.; Rübe, C.; Probst, A.; Jaenke, G.; Bodenstein, H.; Junker, A.; Pott, C.; Schultze, J.; Heinecke, A.; Parwaresch, R.\& Tiemann M. (2001) Primary Gastrointestinal Non-Hodgkin's Lymphoma: I. Anatomic and Histologic Distribution, Clinical Features, and Survival Data of 371 Patients Registered in the German Multicenter Study GIT NHL 01/92. Journal of clinical oncology : official journal of the American Society of Clinical Oncology, Vol. 19, No. 18, (September 2001), pp. 3861-3873, ISSN 1527-7755.

Koch, P.; Probst, A.; Berdel, W.E.; Willich, N.A.; Reinartz, G.; Brockmann, J.; Liersch, R.; del Valle, F.; Clasen, H.; Hirt, C.; Breitsprecher, R.; Schmits, R.; Freund, M.; Fietkau, R.; Ketterer, P.; Freitag, E.M.; Hinkelbein, M.; Heinecke, A.; Parwaresch, R. \& Tiemann, M. (2005) Treatment results in localized primary gastric lymphoma: data of patients registered within the German multicenter study (GIT NHL 02/96). Journal of clinical oncology : official journal of the American Society of Clinical Oncology, Vol. 1, No. 23, (October 2005) pp. 7050-7059, ISSN 1527-7755.

Lévy, M.; Hammel, P.; Lamarque, D.; Marty, O.; Chaumette, M.T.; Haioun, C.; Blazquez, M. \& Delchier, J.C. (1997) Endoscopic ultrasonography for the initial staging and follow-up in patients with low-grade gastric lymphoma of mucosa-associated lymphoid tissuetreated medically. Gastrointestinal Endoscopy, Vol. 46, No. 4, (October 1997), pp. 328-333, ISSN 1097-6779.

Lügering, N.; Menzel, J.; Kucharzik, T.; Koch, P.; Herbst, H.; Tiemann, M. \& Domschke, W (2001). Impact of miniprobes compared to conventional endosonography in the staging of low-grade gastric malt lymphoma. Endoscopy, Vol. 33, No. 10, (October 2001), pp. 832-827, ISSN 1438-8812.

Martinelli, G.; Gigli, F.; Calabrese, L.; Ferrucci, P.F.; Zucca, E.; Crosta, C.; Pruneri, G.; Preda, L.; Piperno, G.; Gospodarowicz, M.; Cavalli, F. \& Moreno Gomez, H. (2009) Early stage gastric diffuse large B-cell lymphomas: results of a randomized trial 
comparing chemotherapy alone versus chemotherapy + involved field radiotherapy. (IELSG 4). Leukemia \& Lymphoma, vol. 50, No. 6, (June 2009), pp. 925931, ISSN 1029-2403.

Montalban, C.; Santon, A.; Boixeda, D. \& Bellas, C. (2001) Regression of gastric high grade mucosa associated lymphoid tissue (MALT) lymphoma after Helicobacter pylori eradication. Gut, Vol. 49, No. 4, (October 2001), pp. 584-587, ISSN 1468-3288.

Nagler, A.K.; Aslanian, H.R. \& Siddiqui, U.D. (2011) Endoscopic ultrasound and gastric lesions. Journal of clinical gastroenterology, Vol. 45, No. 3, (March 2011) pp. 215-21, ISSN 1539-2031.

Neubauer, A.; Thiede, C.; Morgner, A.; Alpen, B.; Ritter, M.; Neubauer, B.; Wündisch, T.; Ehninger, G.; Stolte, M. \& Bayerdörffer, E. (1997) Cure of Helicobacter pylori infection and duration of remission of low-grade gastric mucosa-associated lymphoid tissue lymphoma. Journal of National Cancer Institute, Vol. 89, No., 18, (September 1997), pp. 1350-5, ISSN 1460-2105.

Nobre-Leitão, C.; Lage, P.; Cravo, M.; Cabeçadas, J.; Chaves, P.; Alberto-Santos, A.; Correia, J.; Soares, J. \& Costa-Mira, F. (1998) Treatment of gastric MALT lymphoma by Helicobacter pylori eradication: a study controlled by endoscopic ultrasonography. The American journal of gastroenterology, Vol. 93, No. 5, (May 1998), pp. 732-736, ISSN 1572-0241.

Pavlick, A.C.; Gerdes, H. \& Portlock, C.S. (1997) Endoscopic ultrasound in the evaluation of gastric small lymphocytic mucosa-associated lymphoid tumors. Journal of Clinincal Oncology : official journal of the American Society of Clinical Oncology, Vol. 15, No. 5, (May 1997), pp. 1761-1766, ISSN 1527-7755.

Pavlović, A.R.; Krstic, M.; Tomic, D.; Bjelovic, M.; Jesic, R. \& Suvajdzic N. (2005). Endoscopic ultrasound (EUS) in initial assessment and follow-up of patients with MALT lymphoma treated drug therapy. Acta chirurgica Iugoslavica, Vol. 52, No. 1, pp. 8389, ISSN 0354-950X.

Pinotti, G.; Zucca, E.; Roggero, E.; Pascarella, A.; Bertoni, F.; Savio, A.; Savio, E.; Capella, C.; Pedrinis, E.; Saletti, P.; Morandi, E.; Santandrea, G. \& Cavalli F. (1997) Clinical features, treatment and outcome in a series of 93 patients with low-grade gastric MALT lymphoma. Leukemia \& Lymphoma, Vol.26, No. 5-6, (August 1997), ISSN 1029-2403.

Püspök, A.; Raderer, M,; Chott, A.;.Dragonics, B.; Gangl, A. \& Schofl, R. (2002) Endoscopic ultrasound in the follow up and response assessment of patients with primary gastric lymphoma. Gut, Vol. 51, No. 5, (November 2002), pp. 691-694, ISSN 00175749 .

Radaszkiewicz, T.; Dragosics, B. \& Bauer, P.(1992) Gastrointestinal malignant lymphomas of the mucosa-associated lymphoid tissue. Factors relevant to prognosis. Gastroenterology, Vol 102, No. 5, (May 1992), pp. 1628-1638, ISSN 1528-0012.

Rohatiner, A.; d'Amore, F.; Coiffier, B.; Crowther, D. ; Gospodarowicz, M.; Isaacson, P.; Lister, T. A.; Norton, A. ; Salem, P.; Shipp M. \& R. Somers (1994). Report on a workshop convened to discuss the pathological and staging classifications of gastrointestinal tract lymphoma. Annals of oncology : official journal of the European Society for Medical Oncology / ESMO, Vol. 5, No. 5, (May 1994), pp. 397-400, ISSN 1569-8041. 
Ruskoné-Fourmestraux, A.; Lavergne, A.; Aegerter, P.H.; Megraud, F.; Palazzo, L.; de Mascarel, A.; Molina, T. \& Rambaud, J.L. (2001). Predictive factors for regression of gastric MALT lymphoma after anti-Helicobacter pylori treatment. Gut, Vol. 48, No. 3, (March 2001) pp. 297-303, ISSN 1468-3288.

Ruskoné-Fourmestraux, A.; Dragosics, B.; Morgner, A.; Wotherspoon, A. \& De Jong, D. (2003) Paris staging system for primary gastrointestinal lymphomas, Vol. 52, No. 6, (June 2003), pp. 912-913, ISSN 1468-3288.

Ruskoné-Fourmestraux, A.; Fischbach, W.; Aleman, B.M.; Boot, H.; Du, M.Q.; Megraud, F.; Montalban, C.; Raderer, M.; Savio, A. \& Wotherspoon, A.; on behalf of the EGILS group (2011). EGILS consensus report. Gastric extranodal marginal zone B-cell lymphoma of MALT. Gut, (February 2011), ISSN 1468-3288, [Epub ahead of print].

Sackmann, M,; Morgner, A.; Rudolph, B.; Neubauer, A.; Thiede, C.; Schulz, H.; Kraemer, W.; Boersch, G.; Rohde, P.; Seifert, E.; Stolte, M. \& Bayerdoerffer E. (1997). Regression of gastric MALT lymphoma after eradication of Helicobacter pylori is predicted by endosonographic staging. MALT Lymphoma Study Group, Gastroenterology, Vol. 113, No. 4, (October 1997), pp. 1087-1090 ISSN 1528-0012.

Savio, A.; Franzin, G.; Wotherspoon, A.C.; Zamboni, G.; Negrini, R.; Buffoli, F.; Diss, T.C.; Pan, L. \& Isaacson, P.G. (1996) Diagnosis and posttreatment follow-up of Helicobacter pylori-positive gastric lymphoma of mucosa-associated lymphoid tissue: histology, polymerase chain reaction, or both? Blood. Vol. 87, No. 4, (Februry 1996), pp. 1255-1260, ISSN 1528-0020.

Stathis, A.; Chini, C.; Bertoni, F.; Proserpio, I.; Capella, C.; Mazzucchelli, L.; Pedrinis, E.; Cavalli, F.; Pinotti, G. \& Zucca, E. (2009) Long-term outcome following Helicobacter pylori eradication in a retrospective study of 105 patients with localized gastric marginal zone B-cell lymphoma of MALT type. Annals of oncology : official journal of the European Society for Medical Oncology / ESMO, Vol. 20, No. 6, (June 2009), pp. 1086-1093, ISSN 1569-8041.

Steinbach, G.; Ford, R.; Glober, G.; Sample, D.; Hagemeister, F.B.; Lynch, P.M.; McLaughlin, P.W.; Rodriguez, M.A.; Romaguera, J.E.; Sarris, A.H.; Younes, A.; Luthra, R.; Manning, J.T.; Johnson, C.M.; Lahoti, S.; Shen, Y.; Lee, J.E.; Winn, R.J.; Genta, R.M.; Graham, D.Y. \& Cabanillas, F.F. (1999). Antibiotic treatment of gastric lymphoma of mucosa-associated lymphoid tissue. An uncontrolled trial. Annals of Internal Medicine, Vol. 131, No. 2 (20 July 1999), pp. 88-95, ISSN 1539-3704.

Swerdlow S.H.; S.H.; Campo, E.; Harris, N.L.; Ja_E.S.; Pileri,S.A.; Stein, H.; Thiele, J. \& Vardiman, J.W. (October 2008) WHO Classification of Tumours of Haematopoietic and Lymphoid Tissue (4th edition), World Health Organization, ISBN 9789283224310.

Tari, A.; Asaoku, H.; Kashiwado, K.; Yoshino, T.; Kitadai, Y.; Tanaka S \& Fujihara, M. (2009). Predictive value of endoscopy and endoscopic ultrasonography for regression of gastric diffuse large B-cell lymphomas after Helicobacter pylori eradication. Digestive endoscopy : official journal of the Japan Gastroenterological Endoscopy Society. Vol. 21, No. 4, (October 2009), pp. 219-227, ISSN 1443-1661.

Varas, M.J.; Fabra, R.; Abad, R.; Turró, J.; Espinós, J.C.; Bargalló, D. \& Miquel, J.M. (2006). Endoscopic staging of low-grade gastric MALT lymphoma. Revista española de enfermedades digestivas : organo oficial de la Sociedad Española de Patología Digestiva, Vol. 98, No. 3, (March 2006), pp. 189-195, ISSN 1130-0108. 
Yeh, H.Z.; Chen, G.H.; Chang, W.D.; Poon, S.K.; Yang, S.S.; Lien, H.C.; Chang, C.S. \& Chou, G. (2003). Long-term follow up of gastric low-grade mucosa-associated lymphoid tissue lymphoma by endosonography emphasizing the application of a miniature ultrasound probe. Journal of gastroenterology and hepatology, Vol. 18, No. 2, (February 2003), pp. 162-167, ISSN 0815-9319.

Yi, J.H.; Kim, S.J.; Choi, J.Y.; Ko, Y.H.; Kim, B.T. \& Kim W.S. (2010). 18F-FDG uptake and its clinical relevance in primary gastric lymphoma. Hematological oncology, Vol. 28, No. 2, (June 2010), pp. 57-61, ISSN 1099-1069.

Yoon, S.S.; Coit D.G.; Portlock C.S. \& Karpeh M.S. (2004). The diminishing role of surgery in the treatment of gastric lymphoma. Annals of Surgery, Vol. 240, No. 1, (July 2004 ), pp 28-37, ISSN 0003-4932.

Yücel, C.; Ozdemir, H. \& Işik, S. (1999). Role of endosonography in the evaluation of gastric malignancies. Journal of ultrasound in medicine : official journal of the American Institute of Ultrasound in Medicine, Vol. 18, No. 4, (April 1999), pp. 283-238, ISSN 1550-9613.

Wotherspoon, A.C.; Doglioni, C.; Diss T.C.; Pan L.; Moschini A.; de Boni M. \& Isaacson P.G. (1993). Regression of primary low-grade B-cell gastric lymphoma of mucosaassociated lymphoid tissue type after eradication of Helicobacter pylori. The Lancet, Vol. 342, No. 8871, (September 1993), pp. 575-577, ISSN 0140-6736.

Zucca, E.; Bertoni, F.; Stathis, A. \& Cavalli, F. (2008). Marginal Zone Lymphomas. Hematology/Oncology Clinics of North America, Vol. 22, No. 5,(October 2008), pp. 883901, ISSN 1558-1977

Zucca, E. \& Dreyling, M. (2010). Gastric marginal zone lymphoma of MALT type: ESMO Clinical Practice Guidelines for diagnosis, treatment and follow-up. Annals of Oncology, Vol. 21, No. 5, (May 2010), pp. v175-v176, ISSN 0923-7534.

Zullo, A.; Hassan, C.; Andriani, A.; Cristofari, F.; Cardinale, V.; Spinelli, G.P.; Tomao, S. \& Morini, S. (2010) Primary low-grade and high-grade gastric MALT-lymphoma presentation. Journal of clinical gastroenterology. Vol. 44, No. 5, ( May-June 2010), pp. 340-344. 


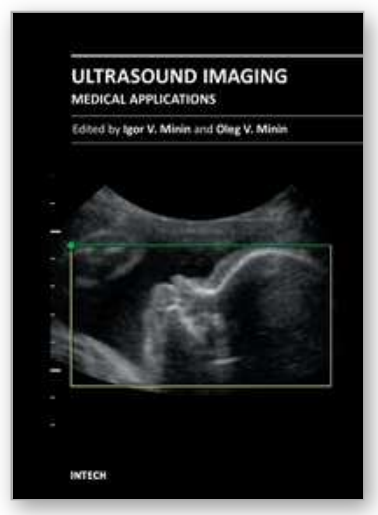

\author{
Ultrasound Imaging - Medical Applications \\ Edited by Prof. Oleg Minin
}

ISBN 978-953-307-279-1

Hard cover, 330 pages

Publisher InTech

Published online 23, August, 2011

Published in print edition August, 2011

This book provides an overview of ultrafast ultrasound imaging, 3D high-quality ultrasonic imaging, correction of phase aberrations in medical ultrasound images, etc. Several interesting medical and clinical applications areas are also discussed in the book, like the use of three dimensional ultrasound imaging in evaluation of Ashermanâ $€^{\mathrm{TM} S}$ syndrome, the role of 3D ultrasound in assessment of endometrial receptivity and follicular vascularity to predict the quality oocyte, ultrasound imaging in vascular diseases and the fetal palate, clinical application of ultrasound molecular imaging, Doppler abdominal ultrasound in small animals and so on.

\title{
How to reference
}

In order to correctly reference this scholarly work, feel free to copy and paste the following:

Calogero Vetro, Alessandra Romano, Giuseppe A. Palumbo, Giacomo Bonanno and Francesco Di Raimondo (2011). Role of the Endoscopic Ultrasonography in the Management of Gastric Lymphomas: Our Experience and Review of Literature, Ultrasound Imaging - Medical Applications, Prof. Oleg Minin (Ed.), ISBN: 978-953307-279-1, InTech, Available from: http://www.intechopen.com/books/ultrasound-imaging-medicalapplications/role-of-the-endoscopic-ultrasonography-in-the-management-of-gastric-lymphomas-ourexperience-and-rev

\section{INTECH}

open science | open minds

\section{InTech Europe}

University Campus STeP Ri

Slavka Krautzeka 83/A

51000 Rijeka, Croatia

Phone: +385 (51) 770447

Fax: +385 (51) 686166

www.intechopen.com

\section{InTech China}

Unit 405, Office Block, Hotel Equatorial Shanghai

No.65, Yan An Road (West), Shanghai, 200040, China

中国上海市延安西路65号上海国际贵都大饭店办公楼 405 单元

Phone: +86-21-62489820

Fax: +86-21-62489821 
(C) 2011 The Author(s). Licensee IntechOpen. This chapter is distributed under the terms of the Creative Commons Attribution-NonCommercialShareAlike-3.0 License, which permits use, distribution and reproduction for non-commercial purposes, provided the original is properly cited and derivative works building on this content are distributed under the same license. 